\title{
DISSEMINATED PARACOCCIDIOIDOMYCOSIS WITH PERIPLEURITIS IN AN AIDS PATIENT
}

\author{
Marcelo CORTI, María F. VILLAFAÑE, Ricardo NEGRONI \& Omar PALMIERI
}

\begin{abstract}
SUMMARY
Paracoccidioidomycosis is one of the most frequent systemic and endemic mycoses of Latin America caused by a dimorphic fungus. In AIDS patients, paracoccidioidomycosis appears as a severe and disseminated disease with a wide spectrum of clinical findings. The CD4 counts are usually less than 200 cell $/ \mu \mathrm{L}$. We present a case of disseminated paracoccidioidomycosis with peripleuritis and subcutaneous abscesses on the chest wall as initial manifestation of AIDS. In endemic countries, paracoccidioidomycosis should be included as an opportunistic infection in AIDS.
\end{abstract}

KEYWORDS: Paracoccidioidomycosis; AIDS; Peripleuritis; Subcutaneous abscess.

\section{INTRODUCTION}

Paracoccidioidomycosis (PCM), South American Blastomycosis or Lutz disease, is a systemic mycosis caused by the thermodimorphic fungus, Paracoccidioides brasiliensis $(\mathrm{Pb})$. It is an endemic mycosis of humid, tropical and subtropical areas, and limited to Central and South America, from Mexico to Argentina. The disease is generally seen in poor people living in rural areas, it has also been described in nonendemic areas, however always in subjects who had lived in or had visited Latin America $^{6,7,14}$.

In normal hosts, $\mathrm{Pb}$ infection is associated with a wide spectrum of clinical aspects; PCM has occasionally been observed in patients with cellular immunity impairment. In patients infected by the human immunodeficiency virus type-1 (HIV-1), the frequency of PCM is low in comparison with other mycoses, such as cryptococcosis and histoplasmosis $^{12,13,18,19}$.

The first cases of this mycosis in AIDS patients were reported in 1989 and, until 1995, 31 cases of this association had been reported ${ }^{3,11,26}$. in Brazil, the estimated incidence of PCM in HIV-1 seropositive patients in 1995 was $0.09 \%$.

We present a patient with advanced HIV/AIDS disease, who developed a disseminated form of PCM with peripleuritis and subcutaneous abscesses in the chest wall, as the initial manifestation of AIDS.

\section{CASE REPORT}

A 36-year-old, white heterosexual male, intravenous drug abuser, and seropositive for human immunodeficiency virus type-1 (HIV-1), was admitted to our service with prolonged fever, weight loss, anorexia and headache. There was no prior history of opportunistic infections, but at examination, his CD4 T count was 8 cell/ $\mu \mathrm{L}$, indicating advanced HIV/ AIDS disease. He reported no previous history of farming or rural activities. Physical exam also showed enlargement of cervical lymph nodes, hepatosplenomegaly and multiple subcutaneous abscesses on the left chest wall and sternum. Chest X-ray revealed a lytic lesion of the $6^{\text {th }}$ and $10^{\text {th }}$ rib, hilar enlargement with homolateral cisuritis, and homogeneous consolidation on the left lower lobe from the thoracic wall to the pulmonary parenchyma; this image was convex in the central part and concave on both sides. The angles of union of this opacity with the chest wall were obtuse (Fig. 1) as described by Skarby in 1939, for peripleuritis or endothoracic fasciitis.

Computed tomography (CT) of the thorax showed osteolytic lesions on the sternum and a soft tissue image in front of this. The parietal pleura thickened at the level of the XII vertebra and there was the presence of a soft tissue density mass and an osteolitic image of the rib at that level (Fig. 2). Percutaneous needle aspiration of both subcutaneous abscesses was performed and direct microscopic exam showed purulent material and the presence of multiple budding yeast cells, characteristic of $\mathrm{Pb}$. Likewise, direct microscopic exam of sputum was positive for $\mathrm{Pb}$.

The patient was treated with itraconazole ( $200 \mathrm{mg} /$ day) during six months and then, he received $100 \mathrm{mg} /$ day as maintenance therapy.

After the first two months, antiretroviral therapy was initiated. One year after onset of symptoms he is in good clinical condition with improvement in his general state and resolution of adenopathy, subcutaneous abscesses and radiological lesions. 


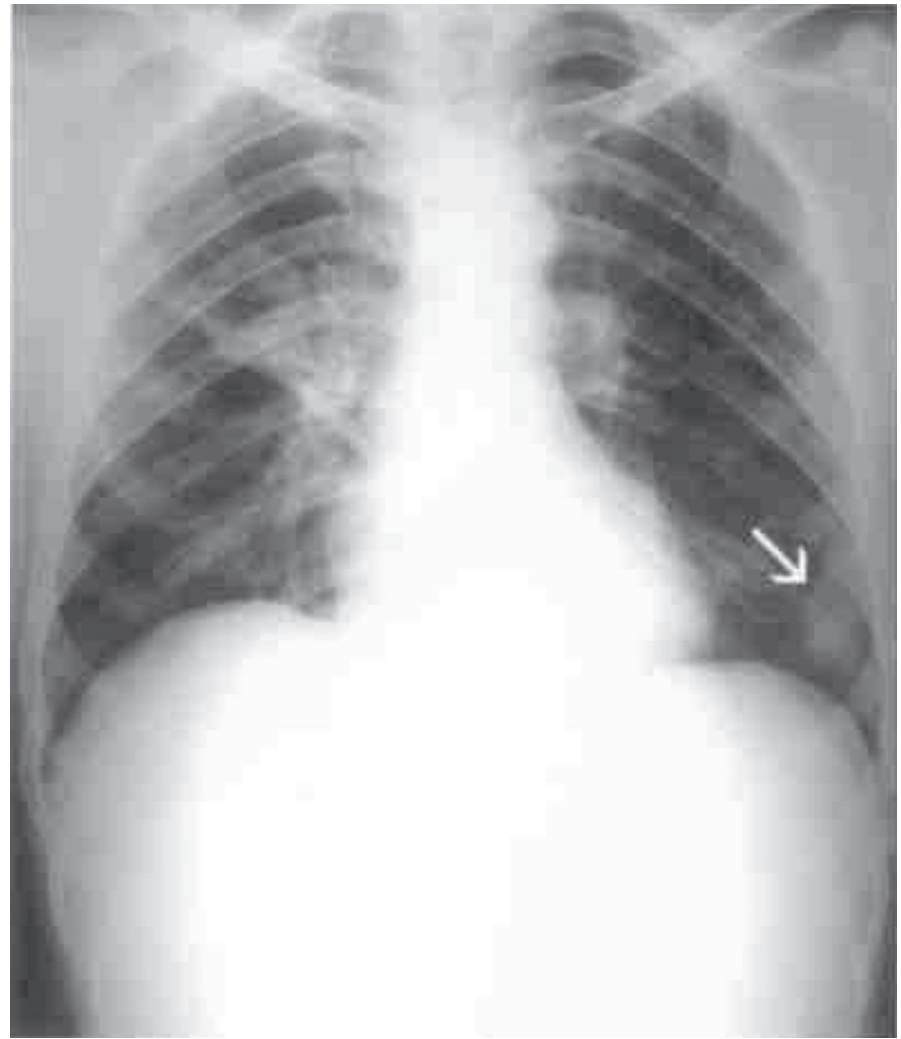

Fig.1 - Chest-X-ray shows a lytic lesion of the $6^{\text {th }}$ and $10^{\text {th }}$ rib and a consolidation on the left lower lobe.

\section{DISCUSSION}

PCM is a rare complication in AIDS patients. In the 10 years after the description of the first patients with this association, less than 50 cases have been published in the medical literature ${ }^{3,8,11,13.14,16,27}$. In fact, the low incidence of PCM in AIDS patients contrasts with the high frequency of cryptococcosis and histoplasmosis in the same population ${ }^{1,2,4,9,20,22}$. Moreover, cryptococcosis and histoplasmosis are associated with an important number of deaths and a high morbidity rate in AIDS patients.

$\mathrm{Pb}$ infection has also been described, albeit rarely, in patients with immunosuppressive diseases other than AIDS, such as solid organ transplant recipients and patients with solid and hematological malignancies. Some authors have suggested that the low incidence of PCM among patients with AIDS in Latin America, might be related to the fact that many AIDS patients receive trimethoprim-sulfamethoxazole and ketoconazole as a prophylaxis or treatment for Pneumocystis carinii pneumonia (PCP) and oropharyngeal candidiasis. Both these drugs are active against $\mathrm{Pb}$ infection ${ }^{25}$. Another possible explanation could be that some cases of pulmonary PCM are diagnosed and treated with co-trimoxazole as PCP (based only on clinical and radiological findings) and both, PCM and PCP, respond to therapy with trimethoprim-sulfamethoxazole. Finally, we should consider the fact that AIDS is predominantly an urban disease in contrast with the rural prevalence of $\mathrm{PCM}^{23}$.

Generally, patients with PCM associated with AIDS are severely immunodepressed at the time of diagnosis, and the CD4 $\mathrm{T}$ counts are below $100 \mathrm{cell} / \mu \mathrm{L}$, as in the present case. PCM is a late complication in AIDS patients and is reportedly the first opportunistic infection in only $31 \%$ of published cases, again similar to our patient.

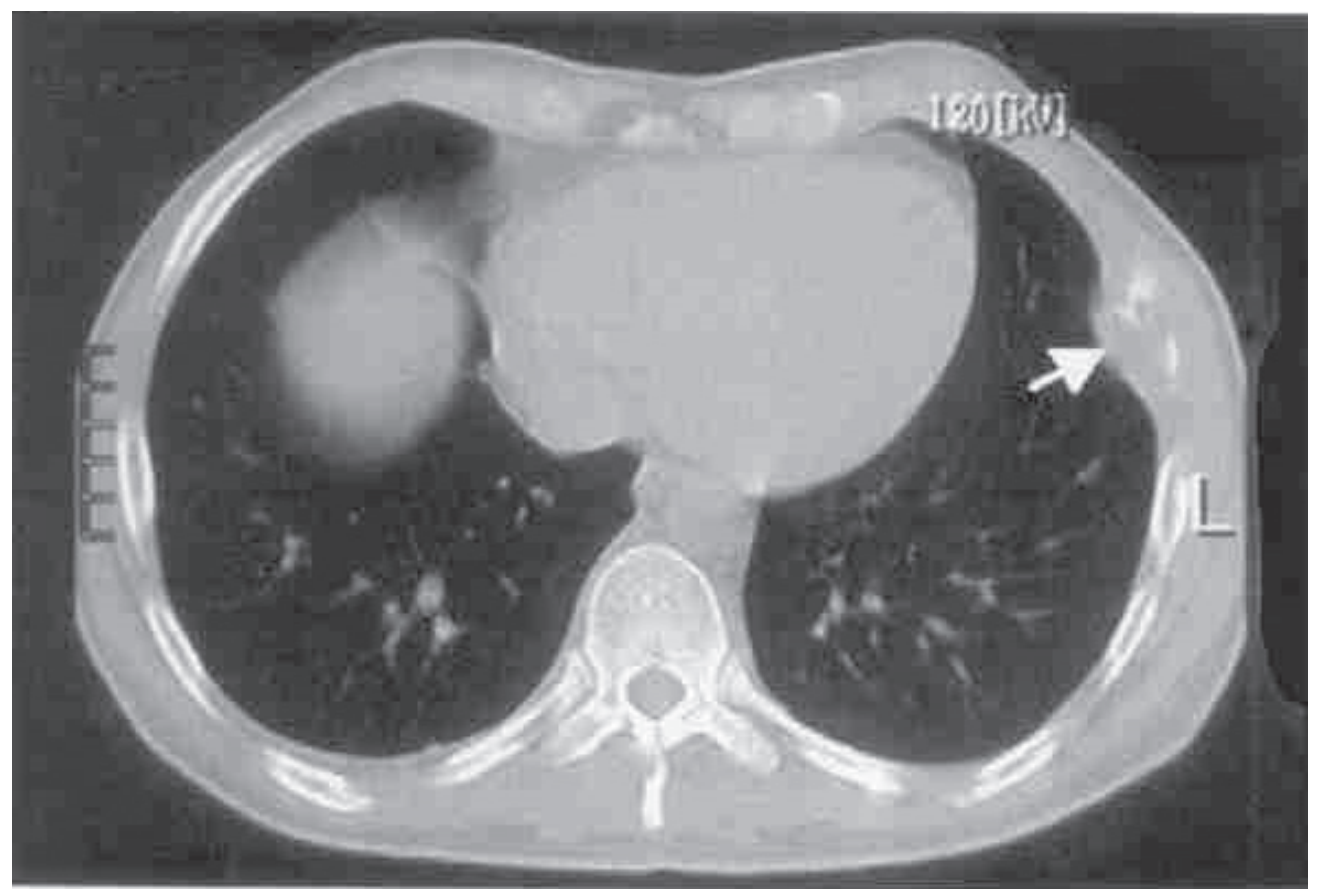

Fig. 2 - Computed tomography of the thorax shows osteolytic lesions on the sternum and a soft tissue image in front of it and at the level of XII vertebra. 
PCM has multiple manifestations and three progressive clinical forms have been recognized: acute, subacute and chronic. PCM associated with AIDS presents as an acute disseminated form or a subacute juvenile form, characterized by multisystemic organ involvement, including malaise, prolonged fever, weight loss, hepatosplenomegaly, enlargement of cervical, inguinal and axillary lymph nodes, cutaneous involvement in form of papules or ulcerating lesions with necrotic areas, pulmonary infiltrates, cerebral mass lesions, and bone involvement with osteomyelitis. Less than $60 \%$ of patients present pulmonary involvement ${ }^{12}$. Our patient also had pleural involvement with peripleuritis and subcutaneous abscesses on the chest wall with costal and sternal osteomyelitis. Bone involvement has been frequently described in the disease ${ }^{5,10,15}$, although there is no reference to the involvement of the endothoracic fascia with peripleuritis. This clinical finding implies the involvement of pleuroparietal lymph nodes with peripleural abscesses, some of which rupture through weak points in the chest wall. In consequence, subcutaneous abscesses can develop, as seen in the patient presented here.

Diagnosis of PCM is confirmed through the observation of multibudding and birefringent yeast cells by direct microscopic examination of biologic fluids (sputum, broncopulmonary secretions) or histopathologic examination of skin and mucosal biopsies, and also by the isolation of the fungus in cultures. Direct microscopic examination is definitive and the gold standard method to identify the fungus in PCM lesions ${ }^{17}$. Culture usually requires a long time, is less sensitive than direct examination and has a high rate of negative results, especially if the samples are contaminated or small in quantity ${ }^{2,21,23}$.

In our patient, direct examination of the purulent exudate obtained from the subcutaneous abscess as well as from sputum samples revealed multiple budding $\mathrm{Pb}$ yeast cells.

Histopathologic studies, including special stains, for example Grocott's methenamine-silver, are also very helpful for the diagnosis, specially when the material is obtained by biopsy. The presence of yeast with thick walls and multiple gemmation is a characteristic of $\mathrm{Pb}$.

Serologic diagnosis relies on the detection of specific antibodies; serologic reactions are useful both as a diagnosis and as a parameter for disease activity assessment.

Methods for detecting circulating antibodies are positive in more than $90 \%$ of patients with active disease; however, in AIDS patients, the antibody levels are lower in comparison with patients without HIV. According to the literature, specific antibodies have been detected in only half of patients tested.

A cutaneous test with paracoccidioidin is negative in AIDS patients and other immunocompromised subjects, in relation to the anergic form of the disease $\mathrm{e}^{17,23}$.

Itraconazole, a triazolic compound with good absorption, is the treatment of choice. Itraconazole is used at an initial dose of $200 \mathrm{mg} / \mathrm{day}$ for 3 months; after this, the dose has to be reduced to $100 \mathrm{mg} / \mathrm{day}$. The efficacy of itraconazole is higher than $93 \%$ with a relapse rate below $7 \%{ }^{23,24}$. The use of itraconazole may be associated with a generally asymptomatic transitory elevation of hepatic enzyme levels. Determination of plasma itraconazole levels is useful because some AIDS patients present hypochlorhydria with lower levels of plasma drug concentration ${ }^{27}$.

The patient was treated with itraconazole and antiretroviral therapy with a good clinical response and tolerance.

Finally, we suggest that in endemic countries, PCM should be included among the opportunistic infections observed in AIDS patients.

\section{RESUMEN}

\section{Paracoccidioidomicosis diseminada con peripleuritis en paciente con SIDA}

La paracoccidioidomicosis es una de las micosis sistémicas endémicas más frecuentes de Latinoamérica, causada por un hongo dimorfo. En los pacientes con SIDA se presenta como una enfermedad grave y diseminada, con un amplio espectro de manifestaciones clínicas. Los niveles de linfocitos T CD4 + son habitualmente $<$ de 200 cél/ $\mu \mathrm{L}$. Presentamos un caso de paracoccidioidomicosis diseminada con peripleuritis y abscesos subcutáneos sobre la pared torácica como manifestación inicial del SIDA. En países endémicos, la paracoccidioidomicosis debe incluirse como una complicación oportunista de los pacientes con SIDA.

\section{REFERENCES}

1. ALVAREZ, M.I. \& POLANIA, L.A. - Criptococosis e histoplasmosis en el Hospital Universitario del Valle, Colombia. Colombia méd., 26: 61-65, 1995.

2. ARANGO, M.; CANO, I.E.; DE BEDOUT, C. et al. - Histoplasmosis y criptococosis diseminada en pacientes con el síndrome de inmunodeficiencia adquirida (SIDA). Acta méd. colomb., 15: 84-91, 1990.

3. BAKOS, L.; KRONFELD, M.; HAMPES, S.; CASTRO, I. \& ZAMPESE, M. Disseminated paracoccidioidomycosis with skin lesions in a patient with AIDS (letter). J. Amer. Acad. Derm., 20: 854-855, 1989.

4. BAVA, A.J. \& NEGRONI, R. - Características epidemiológicas de 105 casos de criptococosis diagnosticados en la República Argentina entre 1981-1990. Rev. Inst. Med. trop. S. Paulo, 34: 335-340, 1992.

5. BORGIA, G.; REYNAUD, L.; CERINI, R. et al. - A case of paracoccidioidomycosis: experience with long-term therapy. Infection, 28: 119-120, 2000.

6. BRUMMER, E.; CASTAÑEDA, E. \& RESTREPO, A. - Paracoccidioidomycosis: an update. Clin. microbiol. Rev., 6: 89-117, 1993.

7. CAstillo, J.; ORdoñeZ, N.; LÓPeZ, S. \& CASTAÑedA, E. Paracoccidioidomicosis: diagnóstico por el laboratorio de 333 casos. Biomédica, 14: 230-239, 1994.

8. CIMERMAN, S.; BACHA, H.A., LADEIRA, M.C.T. ; SILVEIRA, O.S. \& COLOMBO, A.L.. - Paracoccidioidomycosis in a boy infected with HIV. Mycoses, 40: 343-344, 1997.

9. CORTI, M.; CENDOYA C.; SOTO, I. et al. - Disseminated histoplasmosis and AIDS: clinical aspects and diagnostic methods for early detection. AIDS Patient Care \& STDs., 14: 149-154, 2000.

10. FULCINITI, F.; TRONCONE, G.; FAZIOLI, F. et al. - Osteomyelitis by Paracoccidioides brasiliensis (South American Blastomycosis): cytologic diagnosis on fine-needle aspiration biopsy smears: a case report. Diagn. Cytopath., 15: 442-446, 1996. 
11. GOLDANI, L.Z.; MARTINEZ, R.; LALDELL, G.A.M.; MACHADO, A.A. \& COUTINHO, V. - Paracoccidioidomycosis in a patient with acquired immunodeficiency syndrome. Mycopathologia (Den Haag), 105: 71-74, 1989.

12. GOLDANI, L.Z.; COELHO, C.; MACHADO, A.A. \& MARTINEZ, R. Paracoccidioidomycosis and AIDS. Scand. J. infect. Dis., 23: 393, 1991.

13. GOLDANI, L.Z. \& SUGAR, A.M. - Paracoccidioidomycosis and AIDS: an overview. Clin. infect. Dis., 21: 1275-1281, 1995.

14. LACAZ, C.S.; PORTO, E. \& MARTINS, J.E.C. - Paracoccidioidomicose. In: LACAZ, C.S.; PORTO, E. \& MARTINS, J.E.C. Micología médica: fungos, actinomicetos e algas de interesse médico. 8. ed. São Paulo, Sarvier, 1991. p. 248-298.

15. LAMBERTUCCI, J.R.; BOTELHO, J.S. \& MELO, F.H.- Osteomyelitis by Paracoccidioides brasiliensis. Rev. Soc. bras. Med. trop., 35: 271-272, 2002.

16. LIMA, M.A.; VERGARA, M.L.S.; DEMACHKI, S. \& SANTOS, J.A.M. Paracoccidioidomicose em um paciente com a infecção pelo vírus da imunodeficiência humana. Relato de necrópsia. Rev. Inst. Med. trop. S. Paulo, 28: 279-284, 1995.

17. LONDERO, A.T. \& RAMOS, C.D. - Paracoccidioidomicose: estudo clínico-micológico de 260 casos observados no interior do Rio Grande do Sul. J. Pneumol., 16: 129$132,1990$.

18. MARQUES, S.A. \& SHIKANAI-YASUDA, M.A. - Paracoccidioidomycosis associated with immunosuppression, AIDS and cancer. In: FRANCO, M.F.; LACAZ, C.S.; RESTREPO, A. \& DEL NEGRO, G., ed. Paracoccidioidomycosis. Boca Ratón, CRC Press, 1994. p. 393-403.

19. MARQUES, S.A.; CONTERNO, L.O.; SGARBI, L.P. et al. - Paracoccidioidomycosis associated with AIDS. Report of seven cases. Rev. Inst. Med. trop. S. Paulo, 37: 261-265, 1995.
20. METTA, H.; CORTI, M. E.; NEGRONI, R. et al. - Criptococosis diseminada en pacientes con sida: análisis clínico, microbiológico e inmunológico de 51 episodios. Rev. argent. Microbiol., 34: 117-123, 2002.

21. MINAMOTO, G.Y. \& ROSENBERG, A.S. - Fungal infections in patients with acquired immunodeficiency syndrome. Med. Clin. N. Amer., 81: 381-409, 1997.

22. MURILLO, J. \& CASTRO, K.G. - HIV infection and AIDS in Latin America: epidemiologic features and clinical manifestations. Infect. Dis. Clin. N. Amer., 8: $1-11,1994$.

23. NEGRONI, R. - Paracoccidioidomycosis (South American Blastomycosis, Lutz mycosis) Int. J. Derm., 32: 847-859, 1993.

24. NEGRONI, R. \& ARECHAVALA, A.I. - Itraconazole: pharmacokinetics and indications. Arch. med. Res., 24: 387-393, 1993.

25. NISHIOKA, S.A. - Paracoccidioidomycosis and AIDS. Clin. infect. Dis., 22: 1132, 1996.

26. PEDRO, R.J.; AOKI, F.H.; BOCATTO, R.S. et al. - Paracoccidioidomicose e infecção pelo virus da imunodeficiência humana. Rev. Inst. Med. trop. S. Paulo, 31: 119$125,1989$.

27. TOBON, A.M.; OROZCO, B.; ESTRADA, S. et al. - Paracoccidioidomycosis and AIDS report of the first two Colombian cases. Rev. Inst. Med. trop. S. Paulo, 40: 377 381, 1998 .

Received: 19 February 2003

Accepted: 8 January 2004 